\title{
New urban spaces - their heritage and creation
}

\author{
Dariusz Gawel \\ Department of Contemporary Architecture, Faculty of Civil Engineering and Architecture, \\ Lublin University of Technology, email: d.gawel@pollub.pl, ORCID: 0000-0001-5759-1962
}

\begin{abstract}
The paper presents the subject of creating and shaping new urban spaces in the era of globalisation. The analysis of these spatial phenomena covers the biggest cities in the world, i.e. places where the problems of urban development occurs most often. The term 'urban space' is understood as a broad concept that goes beyond the defined public space. New places created in the cities are the human creations resulting from the life necessities and the cultural needs of people. The fast-changing living environment forces users to engage in the process of searching (sometimes even creating) of new, adequate places. Spatial activities transforming the urban environment more and more often reflect the local social initiatives' activity. New relations between a user and the surrounding space are the basis for reviewing the existing division and definition of private, group and public space.
\end{abstract}

Keywords: new urban space, city, heritage, creation (creating)

\section{Introduction}

Nowadays we are witnessing the dominance of metropolises and big cities. It is confirmed by the high urbanisation rate, which according to reports is likely to reach $63 \%$ in 2025 [1]. This paper is an attempt to define the place of a man in urban space affected by fast processes of transformation.

Rapid technical progress and the digitalisation of all processes are clearly starting to appear in the daily activities of the people. Basic life activities and work nowadays in the conditions of fast pace of life acquire other meanings. We spend less time in open spaces; we work more. Distances between the house and the place of work, study or leisure are ever increasing. This results in the need for frequent and fast movement from one place to another, mainly with the use of cars.

We are also looking for new, very individual and sophisticated forms of recreation in our neighbourhood. We are paying more and more for it. Our reward is health, free time, family and, in the end, money. The organisation of the basic living environment is becoming increasingly complicated [2]. In search for suitable solutions, we decide to move to a house with a garden on the outskirts of a city.

The current population of the suburbs of metropolises is much larger than that of the centres themselves. A city is becoming more scattered losing its naturally defined structure. Traditional divisions of space into private, semi-private (group) and public seem to be insufficient in these conditions to define the phenomena taking place in the relations between a contemporary city and a human being. We are increasingly emphasising the importance of space in relation to its use and development, with a view to the future generations [3]. 
The challenges that modern society faces entitle us to perform courageous, yet precise actions in difficult times of globalisation.

\section{Preserved and forgotten heritage}

Until now we were persuaded that shaping of urban space was based on the principles of its organisation. They consisted in mechanisms of ordering forms, such as: differentiation, hierarchy, concentration, orientation or rhythm of its elements.

Today, we increasingly focus on the form itself. We usually concentrate on its distinctiveness and individual features, such as the shape, colour or texture. Observing the accumulation of numerous, sometimes very numerous elements leading to chaos, we begin to less and less understand space through its reference points. This is probably due to the excessive density of objects, especially in the inner city. Buildings covered with billboards, free-standing advertisements that encourage people to shop, and light that emphasises the meaning of the message make us feel lost and confused. Commercial space is pushing its way into the vicinity of monumental buildings, office buildings, schools and even churches ${ }^{1}$ [4].

However, the more modern objects are built, the more often we see the value of historical buildings created in a traditional, natural way with reliable means of composition expression.

What indirectly organises the features of a place is a clearly assigned function of the objects, the scale of the development and attention to detail. The unique significance of a place in space is determined by its special features. A place is an organised world of meanings [5]. Legible architecture, often created in a densely built space, is based on a thoughtful location, composition order that is created with other buildings, and carefully selected urban detail.
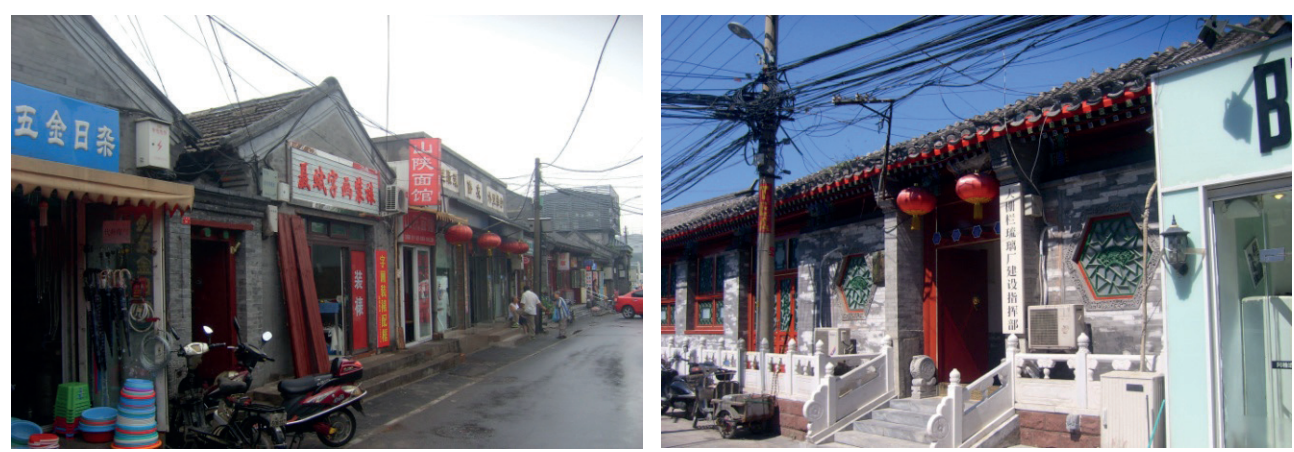

Fig. 1.2. The hutongs in Pekin.The unique atmosphere of an authentic, historic residential area. (Source: Photo author 2013)

Many urban areas have resisted the time constraints despite the modest scale of development and neighbourhood conditions. Their uniqueness lies in the authenticity of their expression, the harmony they create with their surroundings and the respect for the local traditions and people living in the area. This phenomenon can be seen in the centres of Asian cities such as Beijing,

„The urban structure of the Polish market over the last 25 years under the free influence of new commercial functions has undergone many deformations. Attractive functions located inside city malls and shopping centres contribute to the degradation of the external, surrounding streets. Shopping centres scattered throughout the city, isolated from the pedestrian network by car parks, deepen the internal peripheries". 
Nanjing or Bangkok. Old residential colonies located in the vicinity of central historical city squares began to transform into public areas, creating friendly micro-commercial, gastronomic and meeting places. These are primarily Chinese hutongs, which have been the historical living environment for people for centuries [6]. A similar district in the immediate vicinity of the water channels is Pom Mahakan in Bangkok. Here, low wooden residential buildings were built on stilts, creating water housing for a complex of palace and temple buildings.

The transformations of these areas were not originally the decision of the authorities, because as one may expect, the economic attractiveness of the location spoke in favour of using them for other purposes. The determination of local social communities made it possible to maintain and equip forgotten districts with essential technical infrastructure. The statement that places are defined by people who make up the local community is hereby confirmed. Unique persons and magical places have a special role to play [7]. Today, these culturally magical central districts reflect the former life of the inhabitants, thus being a popular tourist destination. The blurred borders between public and semi-private spaces within a residential area are becoming more and more common.

The particular urban spaces known as "non-places"2 give completely different impression (fr. non-lieu) characterised by a lack of changeability, where we stay out of necessity and not of our own free will, and with a large flow of people [8]. These are usually airports, shopping malls, gas stations, but also refugee camps. These spaces are in no way emotionally speaking to their users, but become only a means to achieve a goal by them.

When analysing modern cities, we come to the conclusion that such places are becoming increasingly similar due to the standard of construction and applied elements of equipment. We are not able to recall their individual characteristics, hence the term as if they belonged to nobody [9].
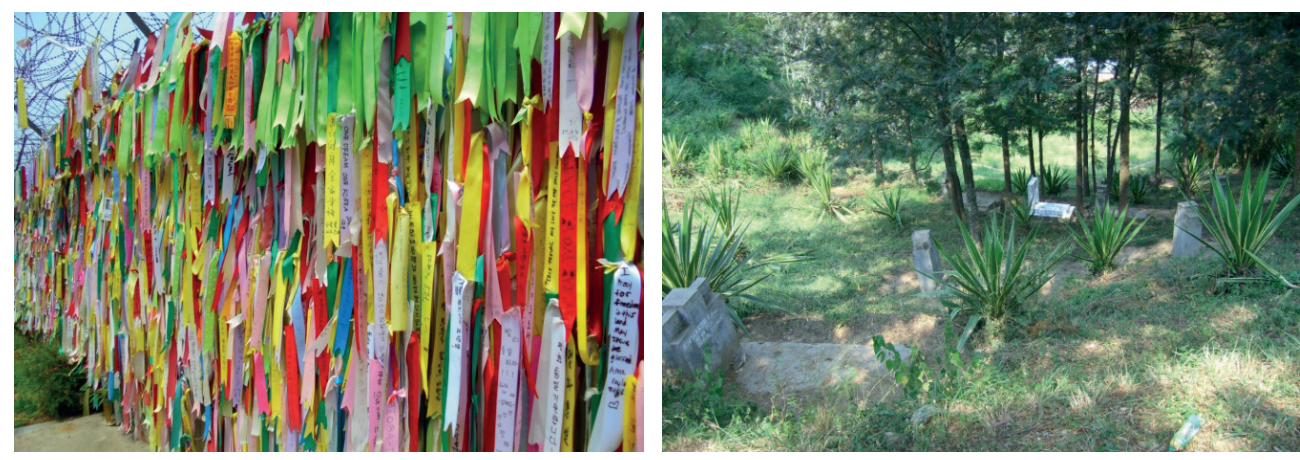

Fig. 3. Not a place of memory in Kigali, after the genocide in Rwanda. (Source: Photo author 2012)

Fig. 4. Not a place of memory, zone of the Korean borderland, commemoration of people deprived of their homeland. (Source: Photo author 2017)

There is another crucial area connected with this term, namely the term "non-place of memory" (fr. non-lieu de memoire). The emerging areas that were tainted with violence, crime and genocide could certainly become historical memorial sites with monuments or other forms

2 "Non - place" - a term created by the French ethnologist, culture anthropologist, Marc Auge, described in [11] who noted that there are areas that are not personalised, that are quickly passable without attention, that are devoid of any features". 
of commemoration. This is not the case if we want to forget rather than commemorate them ${ }^{3}$ [10]. This term is used because of its difficult heritage. Therefore, such places are often undeveloped, abandoned and seemingly forgotten. No one has the courage to transform, rebuild or adapt them. Most frequently they remain in our memory.

\section{Directions of change - urban greenery and traffic}

We very often have a pseudo-modern, foregone image of the city in our minds. Large districts in a form of a maze of viaducts and narrow streets crowded with cars among tall glass buildings. Despite the very latest technologies used to construct the skyscrapers, in most cases it is exclusively about the development of another area. The plundering spatial policy and rising prices of properties are maximising the high-rise buildings in the centres of metropolis. In these places, the economy unquestionably wins with physiological needs and the sense of security of people [12]. A person appearing in such built-up environment is forced to look for their place [13]. We feel increasingly tired and weary in this kind of space. Even the smallest biologically active areas, i.e. lawns and green areas and natural water reservoirs, become an alternative to the concrete construction of city centres.

Mini parks - gardens, called pocket parks - have become an example of the use of the smallest undeveloped spaces. Their name - pocket parks (parklets) derives from the very modest surfaces on which they are created. These small areas of urban greenery combine many different functions. One can relax, have a meal, meet other people or read a book there. Various plant compositions and non-standard urban details show the commitment of the city authorities to maintain these areas. It was the local communities of the residents of the districts that decided to use the undeveloped areas (often in the vicinity of the metro stations). The idea was to maintain close contact between man and nature and to create microclimatic enclaves.
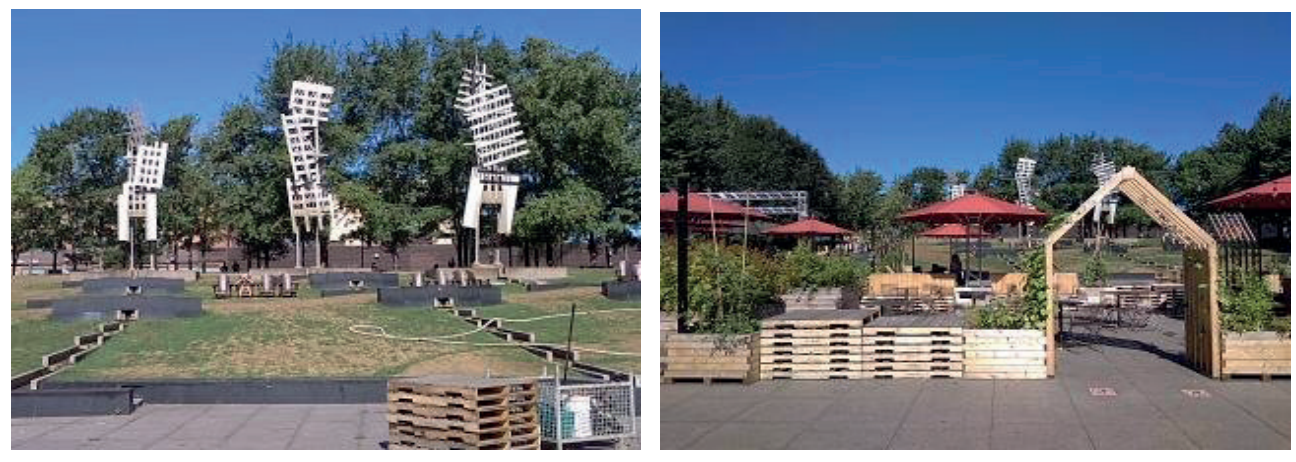

Fig. 5. 6. Montreal - pocket park Jardin Gamelin, immediate vicinity of the metro Berri.

(Source: Photo author 2018)

Community gardens are a completely different example of urban greenery. The idea behind them was to jointly create a recreational and agricultural space. In such gardens, the local community in the district cultivates plants and vegetables, using them for their own consumption needs.

„The lesson to be learned from genocide based on its sacralisation and trivialisation triggers and perpetuates even greater distance, suspicion, hatred and hostility among groups, and thus increases the likelihood of a new disaster. Regardless of the circumstances, they do not reduce the overall amount of violence, nor do they give any ethical insight into the imperfections or the desired form of coexistence between people". 
Initially, they were created in Havana and other Cuban cities. They were to supply the inhabitants with the vegetables that were missing in the shops. Unattractive greenery composed of single trees was used for this purpose. With time, community gardens became accepted in other North American countries, as an alternative to the existing forms of urban greenery. Their additional value is not only joint ownership, but also cooperative cultivation of these areas. Currently, they are most often created in the vicinity of buildings in residential districts, the peripheral zone of big cities, in areas where multi-family block of flats are concentrated.

When observing the directions of changes in the modern urban space, we can conclude that there is a great demand for areas of multifunctional character and diverse use. The problem of many cities is space for public transport. It concerns finding space for both car traffic in the city centre and organised parking spaces. One solution to this turbulent situation is to blur the boundary between pedestrian traffic on the pavement and car traffic on the road. Multifunctional urban spaces, called "woonerfs", are to combine traffic with parking spaces and a leisure area on the promenade diversified by urban detail. They are usually located in the vicinity of the main city centre structures, where there is not enough space for traffic segregation. The characteristic of this space cannot overestimate the important role of the urban detail, which should be developed in order to eliminate the possibility of transit traffic.

Many examples of new spatial phenomena described in this paper should also be assessed on the basis of the social activity of the residents resulting from the care for the transforming urban districts. However, for people to feel a sense of community in action, borders, barriers and fences separating different forms, functions and properties should collapse [14].

\section{Street $\operatorname{art}^{4}$ and aestheticisation of places}

Creative zones increase the value of space in cities. Influencing the users of public space is done in many ways. Designating places for art in multiple neighbourhoods provides additional educational value and diversifies their functionality. Until now, for many people, space for art has been associated with a tall, flat gable wall of a building, and this is not just about street art in the form of colourful murals. In fact, the transformation of cities took place along with the search for new ideas for post-industrial centres. After the shutdown of large production halls, people started to think about their future use. At the same time, the potential of revitalisation activities to restore old, often historic buildings from the turn of the 19th and 20th century has been noticed. Exhibition complexes, galleries, cinemas and shopping centres were perfectly suited for this type of cubature [15]. However, all these buildings had to be heated, equipped, and people encouraged to visit them (for a fee).

4 „Street Art - a field of art created in a public place, usually "on the street” in the form of illegal intervention. The term includes traditional graffiti, but is often used to distinguish between artistic activity in urban space and vandalism" [16]. 

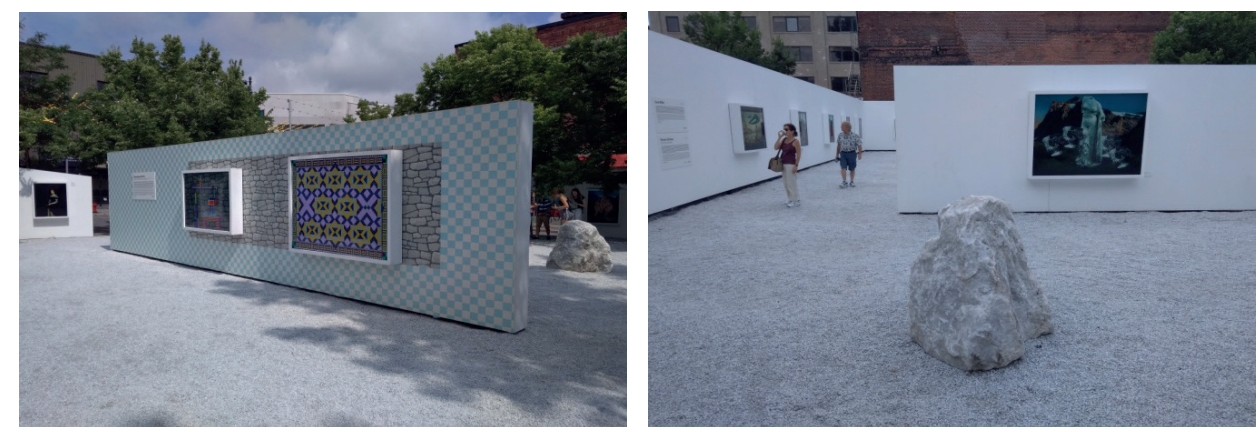

Fig. 7. 8. Montreal - street gallery at Rue Catherine (Rue Panet), in the Le Village district. (Source: Photo author 2018)

Nowadays, street galleries have been an increasingly appreciated idea. Such facilities started to be more often created in Canada, the United States or Europe. Street micro-spaces and squares have started to be perceived as a perfect place to present art in the form of sculptures, paintings and various compositional forms. The element that distinguishes these objects in the public space is most often their vivid, bold colour scheme. A measurable effect of the opening of the district to the community of residents and tourists was a decrease in the number of graffiti on the facades of nearby buildings.

Building the interior of urban street galleries consisted in finding a suitable formula for the presentation of works of considerable size. Street galleries turned out to be such a good idea that groups of quasi-artists began to paint the fences separating the newly built structures within the district in a thoughtful and organised way.

\section{A new perspective or the consolidation of legal divisions?}

The hitherto divisions defining the public space took into account its two basic forms: [17]:

- traffic route - in the form of a street (often expanded with commercial functions),

- city square - as a place of inhabitants' assembly (expanded with various complementary functions),

Other sources supplement this division with all kinds of urban green areas, such as parks, cemeteries and lawns. Concern for the future and the need to ensure access to them raises the question of the legal framework that regulates the functioning of such areas within cities.

In Poland, the notion of public space was used to refer to the common space belonging to the inhabitants. Its organisation and management is the responsibility of the central and local governments. The special significance of public space is guaranteed by the Spatial Planning and Land Development Act. With the increasing competence of local governments, the space started to be treated as a common good of a special importance ${ }^{5}$.

The term appearing in the United States - privately owned public space (POPS), or according to other sources - privately owned public open spaces (POPOS), are used to define a public space accessible to all, but privately owned [18]. Such areas must be made available to all users, as regulated by the provisions in the US Land Use Regulation. Places of common

5 "the area of public space" should be understood as an area of particular importance for satisfying the needs of inhabitants, improving their quality of life and fostering social contacts due to its location and functional and spatial features defined in the study of conditions and directions of spatial development of the commune" [20]. 
character created from private funds usually include squares, arcades, terraces or patios. They are mainly connected with private buildings constructed by developers.

\section{Summary}

In the light of the ongoing discussion about the quality of public space, we recognize it as generally accessible area, which favours human contacts and fulfils their aspirations. Care for the appropriate standard of such areas in the urban structure should be the main goal of the next generations as the protection of the common good [19].

1. The presented cases of creating urban space often result from different mental characteristics of Western (Europe and North America) and Eastern societies (Asia). The perception of public space by these societies is completely different. In Europe, public space is most often associated with monuments, transport and recreational greenery, while in Asia it is place where you can sell, eat or live.

2. The new quality of the social initiative in the transformation of districts should become an important element of citizens' participation in planning processes. Top-down management should be replaced by bottom-up cooperation.

3. Rapid urbanisation leads to the concreting of cities. In search for improvement of this condition, the architectural structures are built that highlight the values of the place and its social and cultural characteristics. Such architecture has a chance to resist the times constraints.

4. Places for the presentation of street art are often created in order to integrate residents into society, allow them to communicate their problems and environmental needs. At the same time, they encourage to take care of the aesthetics of the neighbourhoods.

5. The diversity of created urban spaces shows the fulfilment of very narrow and sublime needs of the inhabitants in the conditions of universal globalisation of cities. They are a complement to the traditional division of space.

6. In the future, consideration should be given to extending the classification of space in order to take into account the current living conditions of the inhabitants. It is particularly important to take into account the conditions of heritage, tradition, culture and art, otherwise they will take the form of "non place".

Table 1. New urban spaces - systematics of research examples. (Source: author)

\begin{tabular}{|c|c|c|c|c|}
\hline & Place & Location & Function & Examples \\
\hline 1 & $\begin{array}{l}\text { Historic residential } \\
\text { district }\end{array}$ & $\begin{array}{l}\text { urban \& historical } \\
\text { areas }\end{array}$ & tourist and leisure & $\begin{array}{l}\text { Hutongs - Pekin } \\
\text { Pom Mahakam-Bangkok }\end{array}$ \\
\hline 2 & Non-place & $\begin{array}{l}\text { urban and suburban } \\
\text { areas }\end{array}$ & $\begin{array}{l}\text { accidental large } \\
\text { groupings of people } \\
\text { connected with } \\
\text { buildings }\end{array}$ & $\begin{array}{l}\text { airports, shopping malls, } \\
\text { gas stations, } \\
\text { refugee camps }\end{array}$ \\
\hline 3 & Non-place of memory & $\begin{array}{l}\text { different places tainted } \\
\text { with violence, crime } \\
\text { and genocide }\end{array}$ & $\begin{array}{l}\text { forgotten places of } \\
\text { negative events }\end{array}$ & $\begin{array}{l}\text { the Korean border } \\
\text { place of genocide in } \\
\text { Rwanda or Cambodia }\end{array}$ \\
\hline 4 & $\begin{array}{l}\text { Pocket park mini park } \\
\text { (parkette) }\end{array}$ & $\begin{array}{l}\text { urban and suburban } \\
\text { areas }\end{array}$ & $\begin{array}{l}\text { urban greenery } \\
\text { recreation and leisure } \\
\left(\max \text { areas } 5000 \mathrm{~m}^{2}\right)\end{array}$ & $\begin{array}{l}\text { Jardins Gamelin } \\
\text { in Montreal }\end{array}$ \\
\hline
\end{tabular}




\begin{tabular}{lllll}
\hline \multicolumn{1}{l}{ Place } & Location & Function & Examples \\
\hline 5 & $\begin{array}{l}\text { Social garden } \\
\text { community garden }\end{array}$ & $\begin{array}{l}\text { urban and suburban } \\
\text { areas }\end{array}$ & $\begin{array}{l}\text { areas of green } \\
\text { and vegetable crops }\end{array}$ & $\begin{array}{l}\text { Warszawa, London, } \\
\text { Montreal, Kraków }\end{array}$ \\
\hline 6 & Woonerf & $\begin{array}{l}\text { downtown } \\
\text { urban areas }\end{array}$ & $\begin{array}{l}\text { pedestrian and traffic } \\
\text { zone, recreation }\end{array}$ & $\begin{array}{l}\text { Lódz, Warszawa, Gliwice } \\
\text { Gdynia }\end{array}$ \\
\hline 7 & Street gallery & $\begin{array}{l}\text { service and residential } \\
\text { areas }\end{array}$ & $\begin{array}{l}\text { exhibition grounds } \\
\text { street art. }\end{array}$ & $\begin{array}{l}\text { street gallery Le Village } \\
\text { in Montreal }\end{array}$ \\
\hline $\begin{array}{l}\text { POPS } \\
\text { Privately Owned } \\
\text { Public } \text { Space }\end{array}$ & $\begin{array}{l}\text { spaces connected } \\
\text { with buildings }\end{array}$ & recreation zone & $\begin{array}{l}\text { squares, arcades, terraces } \\
\text { or patios }\end{array}$ \\
\hline
\end{tabular}

\section{References}

[1] Węcławowicz G., Geografia społeczna miast. PWN. Warszawa 2003, p. 61.

[2] Majer A., Socjologia i przestrzeń miejska. PWN, Warszawa 2010.

[3] Gzell S., „Miasto jako wytwór „,kultur gustu””, Kwartalnik Architektury i Urbanistyki, vol. 3, 2013, p.119.

[4] Racoń-Leja K. „Formy przestrzeni komercyjnej w krajobrazie polskich miast”, Teka Komisji Urbanistyki i Architektury Oddziału PAN w Krakowie, vol. 42, 2014, p.151.

[5] Chmielewski J. M., Teoria urbanistyki w projektowaniu i planowaniu miast. Oficyna Wydawnicza Politechniki Warszawskiej, Warszawa 2001, p. 22.

[6] Lotysz S. Matkowska E., Hutongi trzymają się mocno? Problemy autentyczności w architekturze współczesnych Chin. Biblioteka Cyfrowa Politechniki Krakowskiej. Available: https://suw.biblos. pk.edu.pl/mid18827 [Accessed: 20 Nov 2019]

[7] Jałowiecki B., Globalny świat metropolii. Wydawnictwo Naukowe Scholar, Warszawa 2007, p.35.

[8] „Nie-miejsce”, Wikipedia.org. Available: // https://pl.wikipedia.org/wiki/ [Accessed: 20 Nov 2019]

[9] Paprzyca K., „Miejsca - nie-miejsca w przestrzeni małych miasteczek”, Przestrzeń i Forma, vol. 23 (2), 2015, pp. 09-18.

[10] Bauman Z., Szanse etyki w zglobalizowanym świecie. Wydawnictwo Znak, Kraków 2007, p. 102

[11] Augé M., Non-Places: An Introduction to Anthropology of Supermodernity. Verso, London 1992

[12] Czarnecki B., Przestrzenne aspekty przestępczości. Rozprawy Naukowe 216, Oficyna Wydawnicza Politechniki Białostockiej, Białystok 2011.

[13] Gaweł D., Szafranek A., „Place publiczne, jako przestrzeń stymulująca potrzeby człowieka”, Budownictwo i Architektura, vol. 17(3), 2018, pp. 67- 80. https://www.doi.org/10.24358/Bud-Arch_18_173_05

[14] Polèse M., Stren R., The Social Sustainability of Cities: Diversity and the Management of Change. University of Toronto Press, Toronto 2000.

[15] Gaweł D., "Rebirth of postindustrial architecture in polish towns", Civil and Environmental Engineering Reports, 2012, 1 (9), p.31- 39.

[16] „Street Art”, Wikipedia.org. Available: https://pl.wikipedia.org/wiki/Street_art [Accessed: 20 Nov 2019].

[17] Lorens P., Martyniuk-Pęczek J. (ed.), Problemy kształtowania przestrzeni miejskich. Wydawnictwo „Urbanista”, Gdańsk 2010. p. 21.

[18] „POPS”, Wikipedia.org. Available: https://en.wikipedia.org/wiki/Privately_owned_public_space [Accessed: 20 Nov 2019]

[19] Doorley S., Witthoft S., Make space: How to set the stage for create collaboration. Wiley Publisher, New York 2012.

[20] Ustawa o planowaniu i zagospodarowaniu przestrzennym z dnia 27 marca 2003r., Dz. U. $2003 \mathrm{Nr}$ 80 poz. 717 z późniejszymi zmianami. 


\section{Nowe przestrzenie miejskie - ich dziedzictwo i kreacja}

\section{Dariusz Gawel}

Katedra Architektury Współczesnej, Wydział Budownictwa i Architektury, Politechnika Lubelska, email:d.gawel@pollub.pl,ORCID:0000-0001-5759-1962

Streszczenie: Praca odnosi sie do problematyki tworzenia i kształtowania nowych przestrzeni miejskich w czasach globalizacji. Dokonana analiza zjawisk przestrzennych obejmuje metropolie światowe, czyli miejsca, gdzie problemy rozwoju miast koncentrują się najbardziej. Termin przestrzeń miejska jest traktowany jako szerokie pojęcie, wykraczające poza ramy zdefiniowanej przestrzeni publicznej. Nowe miejsca tworzone w obrębie miast są wytworem człowieka wynikającym z jego potrzeb życiowych i kulturowych. Zmieniające się w szybkim tempie warunki funkcjonowania środowiska zamieszkania, wymuszają na użytkownikach włączenie się w proces poszukiwania (czasem kreacji), nowych adekwatnych miejsc. Działania przestrzenne przeobrażające środowisko miejskie, coraz częściej są wyrazem aktywności lokalnych inicjatyw społecznych. Tworzone nowe relacje pomiędzy użytkownikiem a otaczającą go przestrzenią, stanowią podstawę do zrewidowania dotychczasowego podziału i definicji przestrzeni prywatnej, grupowej i publicznej.

Słowa kluczowe: nowa przestrzeń miejska, miasto, dziedzictwo, kreacja (tworzenie) 
